\title{
PAKARTOTINĖS OPERACIJOS CHIRURGIJOJE: 15 METŲ PATIRTIS
}

\author{
Vinsas Janušonis \\ Klaipedos universitetas
}

Raktažodžiai: pakartotinès operacijos chirurgijoje, sveikatos priežiūros kokybè, nepageidautini ịvykiai.

\begin{abstract}
Santrauka
Darbo tikslas: įvertinti pacientų, kuriems atliktos pakartotinès operacijos, kontingentą ir chirurgijos profilius, pakartotinių operacijų priežastinius veiksnius, rizikos laipsni, išvengiamumo galimybes bei palyginti medikų ir ekspertų vertinimą.

Medžiaga ir tyrimo metodika. Tęstinis tyrimas vykdytas analizuojant 2000-2014 m. nepageidautinu įvykių - pakartotinių operacijų pranešimų formas Klaipedos universitetinèje ligoninejje atskirais laikotarpiais - 2000-2004 m., 2005-2009 m., 2010$2014 \mathrm{~m}$. Tirti 757 pacientų, patyrusių pakartotines operacijas, duomenys pagal amžių, lytị, chirurgijos profili.
\end{abstract}

Rezultatai. Tyrimas parode, kad pakartotinai operuota 0,31 proc. pacientų. Daugiau ketvirtadalio $(27,7$ proc.) nepageidautinu i ivykių buvo pakartotinès operacijos.

Daugiausia pakartotinai operuota dèl pilvo ir endokrininès chirurgijos patologijos profilio pacientu 58,8 proc., daugiau nei puse (51,7 proc.) vidutinès rizikos. Daug pakartotinai operuotų pacientų sirgo onkologine liga (39,8 proc.), 11,2 proc. pakartotinu operacijų susiję su infekcija.

Operavusių chirurgų ir ekspertų nuomonès dèl pagrindinių pakartotinių operacijų priežastinių veiksnių (individualios pacientų charakteristikos $-85,3$ ir 89,6 proc.) bei dèl jų išvengiamumo (pilnai ar dalinai buvo galima išvengti - 60,2 ir 66,7 proc.) buvo panašios.

Išvados. 1. Pagrindiniai pakartotinių operacijų rodikliai - priežastys, rizikos laipsnis, laikotarpis tarp operacijų, operavusių chirurgų ir ekspertų vertinimas analizuojamais laikotarpiais iš esmès nesiskyrè. 2. Pakartotinių operacijų dalis KUL - didelejje daugiaprofilineje išvystytos infrastruktūros teikiančioje ištisą parą skubią medicinos pagalbą aukš- to operacinio aktyvumo ligonineje yra nedidele ir santykinai stabili. 3. Pagrindine pakartotinių operacijų priežastis yra individualios pacientų charakteristikos. Didelè dalis (du penktadaliai) pakartotinai operuotų pacientų sirgo onkologine liga, kas šešta pakartotinè operacija susijusi su infekcija. 4. Didèjant operaciniam aktyvumui ir operaciju skaičiui, augant operacijų sudètingumui, pakartotinių operacijų rizikos laipsnis ir jų neišvengiamumas didèjo. 5. Daugumos - dviejų trečdalių pakartotinių operacijų buvo galima visai ar dalinai išvengti, jeigu būtų taikytos multifaktorinès prevencijos priemonès.

\section{Ivadas}

Chirurgija, kaip intervencinè medicinos sritis (absoliučios daugumos pacientų gydymas susijęs su operacija), yra svarbi grandis sveikatos priežiūros sistemoje ir jos organizacijose. Tai labai sparčiai besivystanti ir tobulejjanti sritis (mažai invazyvi chirurgija, robotai, nanotechnologijos ir kt.). Rezultatus chirurgijoje veikia ne tik žmonès, bet ir technologijos.

Visuomenès ir pacientų požiūris ị sveikatos priežiūrą bei mediciną dažnai formuojamas per chirurgijos prizmę. Tai sietina su masinès informacijos priemonių formuojamu medicinos ịvaizdžiu ir chirurginių intervencijų rizika.

Chirurgijoje ypač išryškejja pacientų, medikų ir vadybininkų sąveika, saugumo lūkesčiai ir savisaugos poreikiai.

Senejjant žmonijai, daugèjant traumatizmui, sergamumui širdies - kraujagyslių ligomis ir véžiu, gerèjant ligų diagnostikai daugèja chirurginių intervencijų skaičius. Per metus pasaulyje atliekama apie 234 milijonai operaciju (vienam iš 25 gyventojų). Europoje operacijos dar dažnesnès - Jungtineje Karalysteje kasmet operuojamas vienas iš aštuonių gyventojų. [1]. Chirurgija vis labiau turi ịtakos visuomenès sveikatai ir žmonių gyvenimo kokybei.

Ligoninèse nepageidautiną ịvykị patiria kas dešimtas besigydantis pacientas, trys ketvirtadaliai jų susiję su chirurgine veikla [2]. Komplikacijų po chirurginès operacijos patiria kas šeštas pacientas [3].

Nepageidautini įvykiai (komplikacijos, klaidos) chirur- 
gijoje yra gana plačiai nagrinėjami [4-7]. Tačiau pakartotinès operacijos aptariamos gana retai ir tai dažniausiai pagal atskirus profilius - širdies chirurgijos [8,9], krūtų [10], skydliaukès, žarnyno [5,47], kasos [11], fundoplikacijų [12], apendektomijų ir cholecistektomijų [13].

Pakartotinè operacija - vienas blogiausių nepageidautinų ịvykių, kurią gali patirti pacientas ir kurios neretai yra išvengiamos $[14,15]$. Operacinès ligoninèse yra labai didelès rizikos nepageidautiniems ịvykiams laukas, vienas „karščiausių taškų“, kur didelė galimybė sulaukti komplikacijų po intervencijos, kurių baigtys kartais būna labai blogos.

Pakartotinès operacijos nenurodomos kaip chirurginès veiklos (chirurgijos paslaugų) kokybės rodiklis [16-20], tačiau jos kai kuriose šalyse registruojamos kaip viena iš pooperacinių komplikacijų. Tą rekomenduoja ir PSO [21,22].

Nemaža dalis autorių, nagrinejjančių nepageidautinus ịvykius chirurgijoje, juos labiau linkę vadinti pooperacinèmis komplikacijomis [23-25].

Tokia traktuote sietina su galimai mažesne gydytojų chirurgų moraline ir gydymo ịstaigų materialine atsakomybe. Taip pat motyvuojama tuo, kad sunku nustatyti, kiek nepageidautinų ịvykių ar komplikacijų (pakartotinių operacijų) paveikè chirurginè veikla ar organizaciniai veiksniai (darbo sąlygos, ịrankiai ir kt.) ir kiek paciento asmeninès charakteristikos [26,27].

Tačiau kai kurie autoriai kritikuoja pooperacinių komplikacijų terminą, nes jis skirtingai suprantamas (pavyzdžiui, kraujavimas po operacijos - komplikacija ar normalus pooperacinis reiškinys) [28]. Dèl pooperacinio kraujavimo pakartotinai operuojama 1,2 proc. pacientų [29].

Pakartotinių operacijų skaičius, ivvairių autorių duomenimis, svyruoja ir priklauso nuo profilių. Pavyzdžiui, po kolorektalinių rezekcijų 7,6 proc. [30], 0,6-5,5 proc. [31], 1-4 proc. [32] reikia pakartotinių operacijų. Atkreiptinas dėmesys, kad dažniausiai analizuojamos pakartotinès operacijos 30 dienų laikotarpiu, rečiau - 90 dienų, todèl jų skaičiai gali skirtis.

Ivairių autorių duomenimis, pakartotinių operaciju skaičius svyruoja nuo 1 iki 9 proc. [30,33-35]. Tose ligoninèse, kur pakartotinès operacijos registruojamos, jų skaičius mažèja. Pakartotines operacijas, kaip ir kitas chirurgines komplikacijas, rekomenduojama registruoti 30 dienų laikotarpiu [7,36], tačiau kiti autoriai jas siūlo registruoti, jeigu ịvyksta 90 dienų laikotarpiu [37-39], nes dalis chirurginių komplikacijų ịvyksta vèliau nei per 30 dienų $[3,40]$, neretai jau išrašius iš ligoninès.

Tačiau kiti autoriai $[8,41-44]$ pakartotines operacijas traktuoja kaip nepageidautinus įvykius ir juos sieja su sveikatos priežiūros kokybe.
Tai patvirtina ir pakartotinių operacijų pagrindinès sisteminès priežastys (pacientų charakteristikos, medikų charakteristikos, komandinis darbas, darbo vieta, technologijos) ir jų sąlygotos antrinès priežastys - keičiamas operacijos metu jos planas ir metodika, per didelè ar per maža operacijos apimtis, nebūtinas veiksmas ar procedūra operacijos metu, netiksli priešoperacinė diagnostika, infekcija, kraujavimas, siūliu nelaikymas, nepakankamai ịvertintas operacijos ir paciento bei medikų individualių charakteristikų santykis. Kitų visų pakartotinių operacijų sisteminès analizès publikacijų ligoninès ar ligoninių grupès lygmeniu rasti nepavyko, nors trys ketvirtadaliai visų nepageidautinų ìvykių chirurgijoje yra susieti su operacijomis, kas dešimtas iš jų - su pakartotinemis operacijomis.

Pakartotinė operacija yra aiškiai apibrěžtas nepageidautinas įvykis, kurị galima paveikti ir taip gerinti sveikatos priežiūros kokybę bei mažinti kaštus.

Neplanuota pakartotinè operacija visada yra nepageidautinas ịvykis, tačiau ne visada yra medikų nesèkmė ar klaida. Tai dažniausiai susiję su paciento individualiomis charakteristikomis ar kitomis priežastimis [45].

Pakartotinių operacijų, kaip nepageidautinų ìvykių, fiksavimas, registravimas ir analizè sudaro prielaidas visų nepageidautinų ịvykių chirurgijoje prevencijai.

Šio tyrimo svarba bei praktinè vertè abejonių nekelia. Tokios apimties panašių tyrimų šalyje atlikta nebuvo.

Darbo tikslas: ịvertinti pacientų, kuriems atliktos pakartotinès operacijos, kontingentą ir chirurgijos profilius, pakartotinių operacijų priežastinius veiksnius, rizikos laipsni, išvengiamumo galimybes bei palyginti medikų ir ekspertų pakartotinių operacijų vertinimus.

\section{Medžiaga ir tyrimo metodika}

2000 m sausio - 2014 m. gruodžio mèn. Klaipėdos universitetineje ligonineje (KUL) buvo vykdoma tęstinio tyrimo, pradèto $2000 \mathrm{~m}$., fragmentinè analizè.

Tyrimo populiacija (tirtų pacientų kontingentas) - KUL stacionare operuoti pacientai. Tyrimo objektas - pakartotinès operacijos.

Pakartotinė operacija apibrěžiama kaip neplanuota operacija, atliekama dèl buvusios operacijos komplikacijos ar jos nepakankamumo, sudètingos ir nenumatytos ligos eigos per tam tikrą laiko tarpą (KUL - 3 ménesius) tam pačiam pacientui. Pakartotinès operacijos pagal rizikos laipsni skirstomos i keturias kategorijas: minimalios rizikos (1), kai pakartotinès operacijos priežastis galèjo sukelti sveikatos sutrikimus, bet nesukèlè arba sukeltas sveikatos sutrikimas yra laikinas; vidutinès rizikos (2), kai pakartotinès operacijos priežastis ir/ar operacija sukèlè laikiną sveikatos sutrikimą, pailgino hospitalizacijos laiką ir buvo 
reikalingos papildomos lèšos gydymui; didelès rizikos (3), kai pakartotinès operacijos priežastis ir/ar pati operacija sukèlè vieno ar kelių organų funkcijos praradimą, laikiną ar nuolatinị darbingumo sumažejimą, pailgino hospitalizacijos laiką ir buvo reikalingos papildomos lèšos gydymui; mirtis po pakartotinès operacijos (4) [37,45].

Darbe analizuojamos pakartotinių operacijų sisteminès priežastys - individualios pacientų ir medikų charakteristikos, komandinio darbo, valdymo veiksniai, darbo sąlygos ir ịrankiai, technologijos.

Individualios paciento charakteristikos - tai amžius, liga, gretutinès ligos, imuniteto sutrikimas, išsekimas, rizikos veiksniai ir kt.

Individualios medikų charakteristikos - tai žinios ir igūdžiai, fizinis - emocinis pasiruošimas operacijai, bendravimo su pacientu gebejjimai (komunikabilumas), pareigingumas ir disciplinuotumas (kokybès procedūrų laikymasis ir kt.).

Komandinis darbas - šio laikmečio operacijų, ypač sudètingų pagrindinè (būtinoji) kokybės sąlyga. Operacijoje neretai dalyvauja keliu profilių chirurgai ir kiti gydytojai, anesteziologai - reanimatologai, anestezistès, operacinès slaugytojos, medicinos technikai su skirtinga patirtimi ir igūdžiais.

Šiuolaikiškai ịrengtos operacinès - darbo vieta, sąlygos ir darbo įrankiai, šiuolaikinès technologijos (čia terminas naudojamas siauresne prasme) - naujausia medicinos technika užtikrina operacijos sèkmę.Konkrečiosios pakartotinių operacijų priežastys - didelès tikimybès operacijos komplikacija, medicininès klaidos ir nesėkmés, aplaidumas, nusikalstama veikla darbe analizuoti prie kitų priežasčių, kadangi jų buvo santykinai nedaug, jos labai išsibarstę ir jų negalima susisteminti.

Tyrimo metodai - literatūros analizè, nepageidautinu ìvykių pranešimų formų retrogradinè analizè, statistinių duomenu grupavimas, lyginamoji turinio analizè.Tyrimui atlikti buvo naudojama KUL nepageidautinų ịvykių pranešimų formų analizè.

Forma paruošta autoriaus. Ją sudaro 7 dalys (informacija apie pacientą ir nepageidautiną ịvykị (a); etapas, kuriame ịvyko nepageidautinas ịvykis (b); sveikatos priežiūros proceso dalis, kurioje ịvyko nepageidautinas ịvykis (c); nepageidautino ịvykio rizikos laipsnis ir pasekmès (d); priežastiniai nepageidautino įvykio veiksniai (e); nepageidautino ịvykio išvengimo galimybès (f) ir ekspertizès išvada (g), jungiančios 45 pozicijas. Formas pildè medikai (chirurgai) pastebejję nepageidautiną îvykị (atlikę pakartotinę operaciją).

Analizuojamu laikotarpiu užpildytos 757 pranešimu formos dèl pakartotinių operacijų. Iš tirtų pacientų, ku- riems buvo atliktos pakartotinès operacijos, 50,5 proc. $(n=382)$ sudare moterys, 49,5 proc. $(n=375)$ - vyrai.

Analizuotos ir lygintos pacientu po pakartotinių operacijų grupès 2000-2004, 2005-2009 ir 2010-2014 metu laikotarpiais pagal chirurgijos profili, amžių ir lytị.

Pažymètina, kad 2010-2014 m. labai išaugo operacijų skaičius, buvo pradètos atlikti labai sudètingos analizuojamų profilių operacijos, įdiegtos naujos diagnostikos ir gydymo technologijos.

Palyginti medikų (chirurgų) ir ekspertų priežastinių veiksnių ir pakartotinių operacijų išvengiamumo galimybiu vertinimai.

Statistinè duomenų analizè atlikta naudojant „SPSS 17,0 for Windows“ ir „Microsoft Office Excel 2003“ programas. Duomenu skirtumas laikytas statistiškai reikšmingas, kai $\mathrm{p}<0,05$ (statistinis pasikliautinumo lygmuo 95 proc.).

\section{Rezultatai ir jų aptarimas}

KUL stacionare 2005-2014 metais atlikta 247050 operacijų, iš jų pakartotiniu - 757 ( 0,31 proc.). Pakartotinai operuota 382 (50,5 proc.) moterys ir 375 (49,5 proc.) vyrai.

Kiti autoriai $[30,31,32,46]$ nurodo didesni pakartotiniu operacijų procentą.

Iš 2736 nepageidautinu ịvykių, užregistruotų analizuojamu laikotarpiu, pakartotinių operacijų buvo $757(27,7$ proc.).

2000-2004 metais operacijų atlikta 54242, iš jų pakartotinių operacijų - 179 (0,33 proc.), 2005-2009 metais atlikta 91046 operacijų, iš jų 283 (0,31 proc.) pakartotinių, 2010-2014 metais 101762 operacijų, iš jų 295 (0,29 proc.) pakartotinès.

Statistiškai patikimo skirtumo tarp pakartotinių operacijų dalies analizuojamais laikotarpiais nestebèta, tačiau matoma pakartotinių operacijų mažėjimo tendencija ryškiai augant operacijų skaičiui. Tai atitinka bendras tendencijas kitose šalyse - operacijų apimtis ir sudètingumas dideja kartu didejja ir nepageidautinų ịvykių (tarp jų pakartotinių operacijų) skaičius [21].

Vidutinis pacientų amžius 58,7 m. (56,3 moterų ir 58,6 vyrų). Esminių skirtumų tarp lyčių nestebėta. Skirtumų susijusių su pacientų amžiumi 2000-2004 m. ir 2005-2009 m. laikotarpiais, nestebèta, tačiau 2010-2014 m. laikotarpiu pacientu amžius padidèjo.

Kiek daugiau pakartotinių operacijų pacientams atlikta 2000-2004 m. $-0,33$ proc. $(\mathrm{n}=179)$ nei 2005-2009 m. 0,31 proc. $(\mathrm{n}=283)$.

Laikas tarp pirmos ir pakartotinès operacijų buvo vidutiniškai 5,5 paros. $2005-2009 \mathrm{~m}$. laikotarpiu jis buvo 0,4 paros ilgesnis - (6 paros) nei 2000-2004 m. (5,6 paros). 
2010-2014 m. šis laikas dar trumpejo ir buvo 5,1 paros. Tai teigiamas rodiklis.

Trumpiausias laikas tarp operacijų buvo neurochirurgijos profilio - 2,5 paros (2 paros 2000-2004 m., 3,1 paros 2005-2009 m. ir 2,5 paros 2010-2014 m.), ilgiausias - pilvo chirurgijos profilio - 6,6 paros (10 paru 2000-2004 m., 6,8 paros 2005-2009 m. ir 4,5 paros 2010-2014 m.).

Panašius rezultatus pateikia ir kiti autoriai. A.M. Almoudaris ir kt. [46] nurodo, kad tarp pirmos ir pakartotinès kolorektalinės operacijos laikas svyruoja nuo 6,5 iki 7 paru (dažniausiai pirmos dvi paros ir 7-9 paros).

Statistiškai patikimo skirtumo analizuojant laiko pokyčius tarp operaciju pagal atskirus profilius analizuojamais laikotarpiais nestebèta, išskyrus trumpejantị laiką tarp pilvo chirurgijos profilio operacijų.

301 (39,8 proc.) pakartotinai operuotu pacientų sirgo onkologinemis ligomis, 85 (11,2 proc.) pakartotinių operacijų buvo susiję su infekcija. Panašius duomenis pateikia ir kiti autoriai. Kable ir kt. [40], analizavę komplikacijas po transureterinès prostatos rezekcijos, histerektomijos, didžiųų sąnarių implantacijos, cholecistektomijų ir išvaržos operacijų, nurodo, kad 1,7 proc. pacientų buvo atliktos pakartotinès operacijos, o 17 proc. atvejų komplikavosi infekcija. Kiti autoriai pateikia duomenis, kad infekcija, kaip pooperacinė komplikacija, pasireiškia 1,2-11 proc. atvejų [16,47-49] nurodo, kad iki pusès pakartotinių operacijų susiję su onkologinèmis ligomis.Pakartotiniu operacijų, susijusių su infekcija, dalis 2005-2009 m. (8,1 proc.) buvo statistiškai reikšmingai mažesnè nei 2000-2004 m. (14,5 proc.) ir 2010-2014 m. (12,2 proc.) Tai susiję su patikslinta infekcijos chirurgijoje samprata.

Su infekcija susijusių pakartotinių operacijų skaičius siekia iki 14,9 proc. [35].

$\mathrm{Su}$ infekcija susijusių pakartotinių operacijų skaičius pagal profilius skiriasi. Pakartotinès operacijos dèl infekcijos po sąnarių artroplastinių operacijų nuo 0,7 iki 1,5 proc. [50], po kolorektalinių rezekcijų $0,84-1,3$ proc. [30].

1 lentelè. Pakartotinių operacijų pasiskirstymas pagal rizikos laipsni

\begin{tabular}{|c|c|c|c|c|}
\hline Metai & 2000-2004 m. & $2005-2009 \mathrm{~m}$. & 2010-2014 m. & Iš viso \\
\hline $\begin{array}{l}\text { Rizikos } \\
\text { laipsnis }\end{array}$ & $n=179$ & $\mathrm{n}=\mathbf{2 8 3}$ & $n=295$ & $n=757$ \\
\hline $\begin{array}{l}\text { Minimalios } \\
\text { rizikos }\end{array}$ & $\begin{array}{c}35 \\
(19,6 \text { proc. })\end{array}$ & $\begin{array}{c}20 \\
(7,1 \text { proc.) }\end{array}$ & $\begin{array}{l}24 \\
(8,1 \text { proc. })\end{array}$ & $\begin{array}{c}79 \\
\text { (10,4 proc.) }\end{array}$ \\
\hline $\begin{array}{l}\text { Vidutinès } \\
\text { rizikos }\end{array}$ & $\begin{array}{c}101 \\
(56,4 \text { proc. })\end{array}$ & $\begin{array}{c}160 \\
(56,5 \text { proc. })\end{array}$ & $\begin{array}{c}130 \\
(44,1 \text { proc.) }\end{array}$ & $\begin{array}{c}391 \\
(51,7 \text { proc. })\end{array}$ \\
\hline $\begin{array}{l}\text { Didelès ri- } \\
\text { zikos }\end{array}$ & $\begin{array}{c}40 \\
\text { (22 proc.) }\end{array}$ & $\begin{array}{c}98 \\
(34,6 \text { proc. })\end{array}$ & $\begin{array}{c}133 \\
(45,1 \text { proc. })\end{array}$ & $\begin{array}{c}271 \\
(35,8 \text { proc.) }\end{array}$ \\
\hline $\begin{array}{l}\text { Mirè po ope- } \\
\text { racijos }\end{array}$ & $\begin{array}{c}3 \\
\text { (1,7 proc.) }\end{array}$ & $\begin{array}{c}5 \\
(1,8 \text { proc.) }\end{array}$ & $\begin{array}{c}8 \\
(2,7 \text { proc. })\end{array}$ & $\begin{array}{c}1,6 \\
\text { (2,1 proc.) }\end{array}$ \\
\hline
\end{tabular}

Sirgusiųjų onkologinėmis ligomis pakartotinai operuotų pacientu dalis analizuojamais laikotarpiais statistiškai patikimai didejo $2010-2014 \mathrm{~m}$. (45,4 proc.) palyginus su 2005-2009 m. (39,2 proc.) ir 2000-2004 m. (31,2 proc.).

Mirštamumas po operacijų, tarp jų ir po pakartotinių operacijų sergančiujjų onkologinèmis ligomis, yra didesnis [51].

Daugiausia atlikta pilvo ir endokrininès chirurgijos profilio pakartotiniu operaciju - 445 (58,8 proc.), antroje vietoje akušerijos-ginekologijos - 104 (13,7 proc.), trečioje - neurochirurgijos - 91 (12 proc.).

Po jų seka krūtinès chirurgijos (54-7,1 proc.), urologijos (23-3 proc.), akių ligų (14-1,8 proc.) traumų (10-1,3 proc.), veido ir žandikaulių chirurgijos (4-0,5 proc.) profilių pakartotinès operacijos.

Statistiškai reikšmingai 2010-2014 m. sumažèjo neurochirurgijos profilio pakartotinių operacijų dalis (3,0 proc.) ir padidejo pilvo ir endokrininès chirurgijos (77,9 proc.) profilių dalis palyginus su 2000-2004 m. ir 2005-2009 m. laikotarpiais.

Tai sietina su struktūriniais pokyčiais (labiau specializuoti neurochirurgijos, pilvo chirurgijos bei akušerijosginekologijos profiliai), pagerejusiais pranešimais apie pakartotines operacijas (akušerijos-ginekologijos, pilvo chirurgijos profiliai), didèjančiu sudètingų operacijų skaičiumi, pagerejusiomis pilvo chirurgijos, neurochirurgijos ligų ir traumų diagnostikos (naujos kartos kompiuterinès ir magnetinio rezonanso tomografijos, echoskopijos) ir gydymo (fluorescencinis mikroskopas, navigacine sistema ir kt.) galimybemis. Pažymètina ir esminis darbo sąlygų pagerejjimas renovavus operacines.

Iš 757 pakartotinių operacijų daugiausia - $391(51,7$ proc.) priskirtinos vidutinei rizikai, mažiausiai - $16(2,1$ proc.) susijusios su pacientų mirtimi (1 lentelè).

Statistiškai patikimai 2005-2009 m. ir 2010-2014 m. mažèjo minimalios rizikos ir didejjo didelès rizikos pakartotinių operacijų palyginus su 2000-2004 m. laikotarpiu. Tai sąlygojo išaugusios diagnostikos ir gydymo galimybės, labai padidèjęs sudètingų operacijų skaičius bei išaugęs rizikos laipsnis priimant sprendimus, esant bent mažiausiai galimybei padèti pacientui.

Mirštamumas po pakartotinių operacijų analizuojamu laikotarpiu nèra didelis ( 1,1 proc.), tačiau jis yra neišvengiamas ir didesnis nei po pirmos operacijos [15]. Po kolorektalinių pakartotinių operacijų mirštamumas dèl ịvairių priežasčių siekia $11,1-16,8$ proc. $[43,46]$.

KUL kiekvieną pakartotinę operaciją tiria bei vertina operavę gydytojai ir ekspertai.

Analizuojant pakartotinių operacijų priežastinius veiksnius (2 lentelè), nustatyta, kad dažniausia pakartotinès operacijos priežastis - individualios pacientų charakteris- 


\begin{tabular}{|c|c|c|c|c|c|c|c|c|}
\hline & 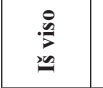 & $\frac{n}{n}$ & $\stackrel{n}{n}$ & $\frac{\mathscr{m}}{\tilde{n}}$ & $\mathscr{\mathscr { D }}$ & $\frac{n}{n}$ & $\frac{\mathscr{m}}{\tilde{n}}$ & $\mathscr{\mathscr { n }}$ \\
\hline 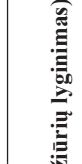 & 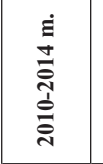 & 㖕 & 謍 & $\frac{n}{n}$ & $\frac{n}{2}$ & 戀 & $\frac{n}{n}$ & $\frac{2}{2}$ \\
\hline 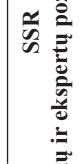 & 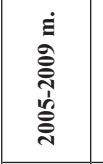 & $\tilde{z}_{n}^{n}$ & 罯 & $\frac{n}{n}$ & $\frac{n}{2}$ & $\sum_{n}^{n}$ & $\stackrel{\infty}{\varpi}$ & $\mathscr{\mathscr { n }}$ \\
\hline 气्ञ & 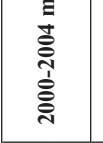 & $\tilde{z}_{n}^{n}$ & 罯 & $\frac{\mathscr{L}}{n}$ & $\mathscr{\mathscr { L }}$ & $\frac{n}{n}$ & $\frac{n}{n}$ & 彎 \\
\hline & $\frac{5}{2}$ & 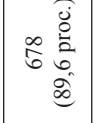 & 接 & 皇 & 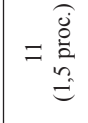 & & & 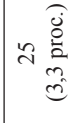 \\
\hline E & 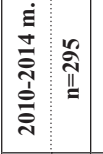 & 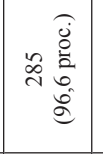 & 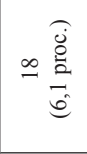 & 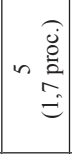 & 施 & & 胥 & di \\
\hline$\frac{5}{\frac{5}{4}}$ & 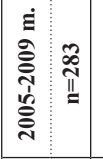 & 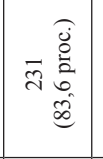 & 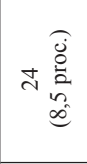 & $=0$. & 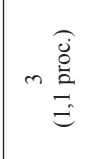 & & & \\
\hline & 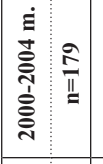 & 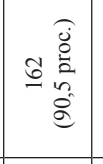 & 绻 & 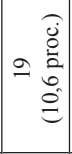 & 施 & & 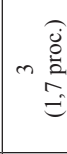 & \\
\hline & $\frac{2}{2} \frac{\hbar}{2}$ & 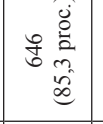 & 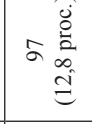 & $=$ & & 3 & $=$ & 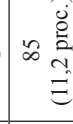 \\
\hline & 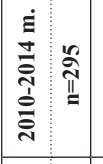 & 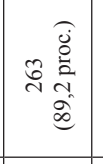 & 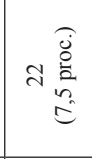 & | & & 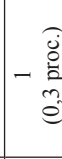 & ( & \\
\hline$\frac{\tilde{g}}{2}$ & 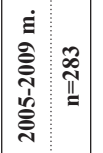 & 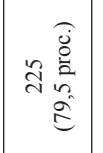 & 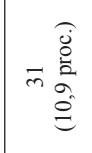 & 雨 & & $\frac{7}{8}$ & 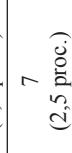 & 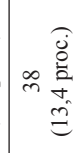 \\
\hline & 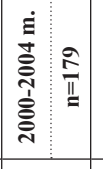 & 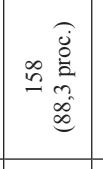 & 辡 & $\infty$ & & . & 八 & \\
\hline & 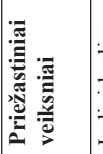 & 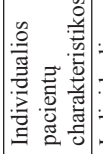 & & & 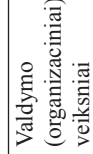 & 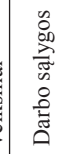 & 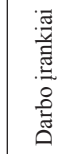 & \\
\hline
\end{tabular}

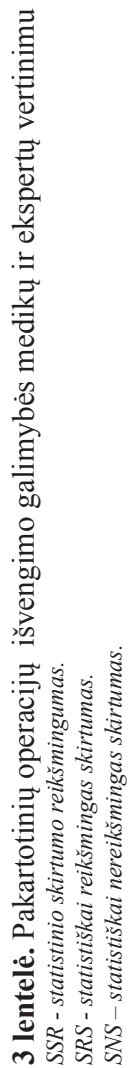

\begin{tabular}{|c|c|c|c|c|}
\hline & 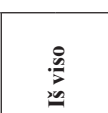 & $\frac{n}{2}$ & $\ddot{\mathscr{n}}$ & $\mathscr{\%}$ \\
\hline & 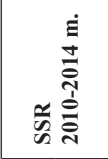 & 筀 & $\stackrel{\mathscr{L}}{\mathscr{\omega}}$ & $\frac{n}{n}$ \\
\hline & 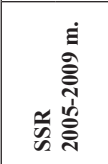 & $\frac{n}{n}$ & $\frac{n}{n}$ & $\frac{n}{5}$ \\
\hline 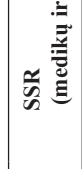 & 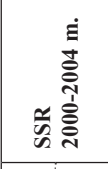 & $\frac{n}{2}$ & $\frac{n}{n}$ & $\frac{\mathscr{D}}{\infty}$ \\
\hline & 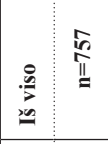 & 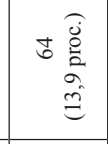 & 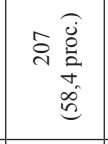 & 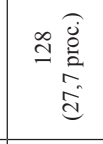 \\
\hline & 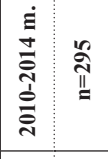 & 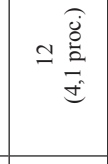 & 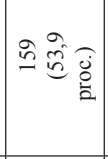 & 士 \\
\hline & 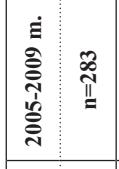 & 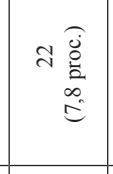 & 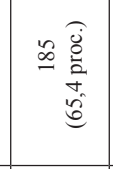 & 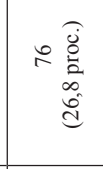 \\
\hline 旁 & 童 & 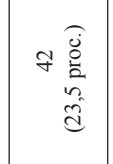 & 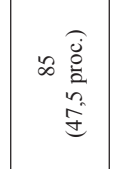 & 哭 \\
\hline & 商 & 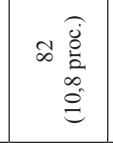 & 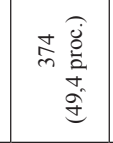 & 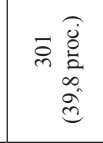 \\
\hline & 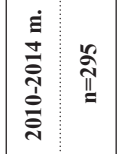 & đ产 & 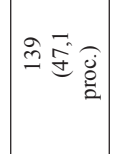 & 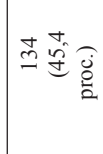 \\
\hline & 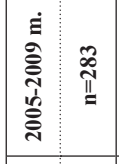 & 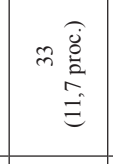 & 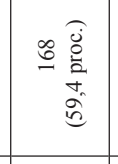 & 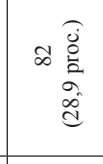 \\
\hline 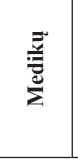 & 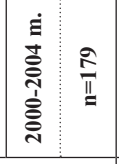 & 无产 & 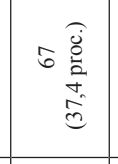 & 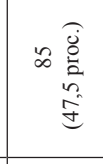 \\
\hline & 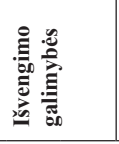 & 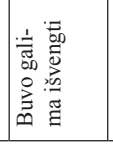 & & \\
\hline
\end{tabular}


tikos ( 85,3 proc. medikų ir 89,6 proc. ekspertų vertinimu). Antroje vietoje - individualios mediku charakteristikos (12,8 proc. ir 12,4 proc.). Statistiškai reikšmingo skirtumo analizuojamais laikotarpiais medikų ir ekspertų vertinime nestebèta.

Vertinant komandinio darbo ir valdymo (organizacinius) veiksnius medikų ir ekspertų vertinimas statistiškai patikimai skiriasi. Ekspertai dažniau mato komandinio ir organizacinio darbo trūkumus.

Dèl pakartotinių operacijų išvengiamumo (3 lentelè) medikų ir ekspertų nuomonès sutapo, kad daugiau nei pusès pakartotinių operacijų buvo galima visiškai ar dalinai išvengti.Statistiškai reikšmingai didejjo pakartotinių operacijų, kurių buvo galima išvengti skaičius ekspertų vertinimu, bei mažèjo pakartotinių operacijų, kurių nebuvo galima išvengti medikų vertinimu 2005-2009 m. laikotarpiu, palyginus su 2000-2004 $\mathrm{m}$.

Tačiau 2010-2014 m. ekspertų vertinimu statistiškai reikšmingai sumažèjo pakartotinių operacijų, kurių buvo galima išvengti ir padidejjo operacijų, kurių nebuvo galima išvengti dalis su kitais analizuojamais laikotarpiais. Tai sietina su operacijų sudètingumu, didesniu rizikos laipsniu priimant sprendimą operuoti.

Pakartotinès operacijos, kurių buvo galima išvengti, pagal profilius pasiskirste beveik tolygiai, statistiškai reikšmingo skirtumo nebuvo.

Atkreiptinas dèmesys ị tai, kad vertindami pakartotinès operacijos priežastinius veiksnius, rizikos laipsnị, išvengiamumo galimybę operavę gydytojai ir ekspertai yra skirtingose išeities pozicijose [52].

Darydami operaciją gydytojai pagal turimus klinikinius ir kitus duomenis planuoja savo veiksmus, juos atlieka ir prognozuoja rezultatą. Ekspertai vertina jau atliktus veiksmus (operaciją) ir žinomus rezultatus.

Be to, tiek gydytojai profesionalai praktikai, tiek ekspertai turi savo supratimą apie riziką, kuris kartais nesutampa.

Operacijos rizika, kaip ir rizika aplamai, yra sunkiai pamatuojama kiekybiškai. Todèl subjektyvios ir objektyvios rizikos atliekant operaciją vertinimas gydytojų ir ekspertų yra skirtingas $[52,53,54]$. Dar labiau skirtingas yra visuomenès, pačių pacientų, teismų ir kitų institucijų vertinimas [45,55].

Pažymètina, kad net to paties įvykio (pakartotinès operacijos) atskirų ekspertų ar jų grupių vertinimas skiriasi labai ryškiai $[37,44]$.

Analizuojamu laikotarpiu buvo viena pakartotinè operacija dèl pirmos operacijos metu palikto svetimkūnio, nors kiti autoriai $[4,56]$ nurodo, kad tokių atvejų, ypač didelèse daugiaprofilinèse ligoninèse, kur teikiama skubi chirurginè pagalba, pasitaiko neretai.

\section{Išvados}

1. Pagrindiniai pakartotinių operacijų rodikliai priežastys, rizikos laipsnis, laikotarpis tarp operacijų, operavusių chirurgų ir ekspertų vertinimas analizuojamais laikotarpiais iš esmès nesiskyrè.

2. Pakartotinių operacijų dalis KUL - didelèje daugiaprofilinèje išvystytos infrastruktūros teikiančioje ištisą parą skubią medicinos pagalbą aukšto operacinio aktyvumo ligoninèje yra nedidelè ir santykinai stabili.

3. Pagrindinè pakartotinių operacijų priežastis yra individualios pacientų charakteristikos. Didelè dalis (du penktadaliai) pakartotinai operuotų pacientų sirgo onkologine liga, kas šešta pakartotinè operacija susijusi su infekcija.

4. Didejjant operaciniam aktyvumui ir operacijų skaičiui, augant operacijų sudètingumui, pakartotinių operacijų rizikos laipsnis ir jų neišvengiamumas didejo.

5. Daugumos - dviejų trečdalių pakartotinių operacijų buvo galima visai ar dalinai išvengti, jeigu būtų taikytos multifaktorinès prevencijos priemonès.

\section{Literatūra}

1. Reid J, Clarke J. Progressing safer surgery. Journal of Perioperative Practice 2009:19:336-341.

2. Zegers M, Bruijne MC, Keizer B. et al. The incidence, root-causes, and outcomes of adverse events in surgical units: implication for potential prevention strategies. Patient Safety in Surgery 2011; 5:13-13. http://dx.doi.org/10.1186/1754-9493-5-13

3. Many complications occur after discharge. Nursing 2013; 4:27-27.

4. Gawande AA, Studdert DM, Orav EJ. et al. Risk factors for retained instruments and sponges after surgery. New England Journal of Medicine 2003; 348:229-235.

http://dx.doi.org/10.1056/NEJMsa021721

5. Beck DE. Reoperative surgery: what can we learn from ar large randomized prospective trial? Clinics in Colon and Rectal Surgery 2006; 19:247-250.

http://dx.doi.org/10.1055/s-2006-956447

6. Ducker M, Faber M, Cruijsberg J. et al. Safety and Risk Management Interventions in Hospitals: A. Systematic Review of the Literature. Medical Care Researche and Review 2009; 66:905-1195.

http://dx.doi.org/10.1177/1077558709345870

7. Bergs J, Hellings I, Zurel O. et al. Systematic review and metaanalysis on the effect of the World Health Organization surgical safety checklist on postoperative complications. British Journal of Surgery 2014; 101:150-158. http://dx.doi.org/10.1002/bjs.9381

8. Yongherg B, Hatlie MJ, eds. The Patients Safety Handbook. Boston: Jones and Bartlett; 2004.

9. Crooke GA, Schwartz CF, Ribakova GH et al. Retrograde arterial perfusion, not incision location, significantly increases the risk of stroke in reoperative mitral valve procedures. The Annals of Thoracic Surgery 2010; 89:723-729.

http://dx.doi.org/10.1016/j.athoracsur.2009.11.061 
10. Spilsburg K, Semmens JB, Saunders CM. Subsequent surgery after initial breast conserving surgery: a population based study. ANZ Journal of Surgery 2005; 75:260-264. http://dx.doi.org/10.1111/j.1445-2197.2005.03352.x

11. Schnelldorfer T, Lewin DN, Adams DB. Reoperative surgery for chronic pancreatitis: is it safe? World Journal of Surgery 2006; 30:1321-1328. http://dx.doi.org/10.1007/s00268-005-7908-8

12. Tsunoda S, Jamieson GG, Devitt PG. et al. Early reoperation after laparoscopic fundoplication: the importance of routine postoperative contrast studies. World Journal of Surgery 2010; 34:79-84. http://dx.doi.org/10.1007/s00268-009-0217-x

13. Chih-Yuan Fu, Chi-Hsun Hsieh, Chun-Han Shih. et al. The Effects of Repeat Laparoscopic Surgery on the Treatment of Complications Resulting from Laparoscopic Surgery. American Surgeon 2012; 78:926-932.

14. Janušonis V. Nepageidautini ịvykiai sveikatos priežiūroje: pakartotinès operacijos. Mokslinès - praktinès konferencijos. "Nepageidautini ịvykiai sveikatos priežiūroje: pakartotinès operacijos" pranešimų tezès, 2005; 1-1.

15. Faiz O, Warusavitarne J, Bottle A. et al. Nonselective excisional colorectal surgery in English National Health Service Trusts: a study pf outcomes from Hospital Episode Statistics Data between 1996-2007. American Journal of Colorectal Surgery 2010; 210:390-401.

http://dx.doi.org/10.1016/j.jamcollsurg.2009.11.017

16. Gawande A. Complications: A Surgeons Notes on an Imperfect Science. NYI.:2002.

17. Kaafarani HM, Rosen AK, Borzecki A, Itani KM. Validity of surgical quality indicators: Opportunities and concerns. The American College of Surgeons 94th Annual Clinical Congress 2009; Abstracts: 193-193.

18. Vincent Ch. How to improve patient safety in surgery. Journal of Health Services Research and Policy 2010;15 Suppl:40-43. http://dx.doi.org/10.1258/jhsrp.2009.09s103

19. Osborne NH, Nicholas LH, Ryan AM. et al. Association of hospital participation in a Quality reporting program with surgical outcomes and expenditures for medicare beneficiaries. Journal of the American Medical Association 2015; 313:496-504. http://dx.doi.org/10.1001/jama.2015.25

20. Etzioni DA, Nabil W, Dueck AC. et al. Association of Hospital Participation in Surgical Outcomes Monitoring Program With Inpatient Complications and Mortality. Journal of the American Medical Association 2015; 313:505-511.

http://dx.doi.org/10.1001/jama.2015.90

21. Weiser TG, Regenbogen SE, Thompson KD. et al. An estimation of the global volume of surgery: a modeling strategy based on available data. Lancet 2008; 372:139-144. http://dx.doi.org/10.1016/S0140-6736(08)60878-8

22. Levy SM, Senter CE, Hawkins RB. et al. Implementing a Surgical checklist: more than checklist a box. Surgery 2012; 152:331-336.

http://dx.doi.org/10.1016/j.surg.2012.05.034

23. Vincent C, Patient Safety. London: Wiley- Blackwell, 2010. http://dx.doi.org/10.1002/9781444323856

24. Dindo D, Clavien PA. What is surgical complication? World
Journal of Surgery 2008; 32:939-942.

http://dx.doi.org/10.1007/s00268-008-9584-y

25. Pinto A, Faiz O, Bicknell C, Vincent C. Surgical complications and their implications for surgeons' well-being. British Journal of Surgery $2013 ; 100: 1748-1755$.

http://dx.doi.org/10.1002/bjs.9308

26. Ghaferi AA, Birkmeyer JD, Dimick JB. Variation in hospital mortality associated with in patient surgery. New England Journal of Medicine 2009; 361:1368-1375. http://dx.doi.org/10.1056/NEJMsa0903048

27. Talsma A, Jones K, Liu G, Cambell DA. Failure to rescue measure: validation of community and hospital - acquired complications. Journal of Nursing Administration 2010; 40:417-423. http://dx.doi.org/10.1097/NNA.0b013e3181f2eb5b

28. Francs JG. Complications after discharge for surgical patients. ANZ. Journal of Surgery 2004; 74:805:807.

29. Grinberg R, Helling TS. A betrayal of our handiwork: postoperative hemorrhage and the need for reoperation. American Surgeon 2009; 12:1242-1246.

30. Ricciardi R, Roberts PL, Read TE. et al. How often do patients return to the operating room after colorectal resections? Colorectal Disease 2011; 14:515-521. http://dx.doi.org/10.1111/j.1463-1318.2011.02846.x

31. Guller U, Rosella L, Karanicolas PJ. et al. Population - based trend analysis of 2813 patients undergoing laparoscopic sigmoid resection. British Journal of Surgery 2010; 97:79-85. http://dx.doi.org/10.1002/bjs.6787

32. Ourian AJ, Nasseri Y, Murrell Z. et al. A prospective study of the association between surgeon experience and Short-term patient outcomes after colorectal surgery. American Surgeon 2010; 76: 1167-1171.

33. Haynes AB, Weiser TG, Berry WR. et al. A surgical safety Checklist to reduce morbidity and mortality in a global population. New England Journal of Medicine 2009; 360:491-499. http://dx.doi.org/10.1056/NEJMsa0810119

34. Sewell M, Adebibe M, Jayakumar P. et al. Use of the WHO surgical safety checklist in trauma and orthopedic patients. International Orthopedics 2011; 35:897-901. http://dx.doi.org/10.1007/s00264-010-1112-7

35. Kwok AC, Funk LM, Baltaga R. et al. Implementation of the World Health Organization Surgical Safety checklist, including introduction of pulse oximetry, in a resource - limited setting. Annals of Surgery 2012; 257:633-639. http://dx.doi.org/10.1097/SLA.0b013e3182777fa4

36. Weiser TG, Haynes AB, Lashoher A. et al. Perspectives in quality: designing the WHO Surgical Safety Checklist. International Journal of Quality in Health Care 2010; 22:365-370. http://dx.doi.org/10.1093/intqhe/mzq039

37. Janušonis $\mathrm{V}$. Reoperative surgery and health care quality. Bridges 2010; 3:173-180.

38. Shanafelt TD, Balch CM, Bechamps G. et al. Burnout and medical errors among American surgeons. Annals of Surgery 2010; 251:995-1000. http://dx.doi.org/10.1097/SLA.0b013e3181bfdab3

39. Glasson EN, Pedersen AB, Hansen TB. Risk of re-admission, reoperation, and mortality within 90 days of total hip and knee arthroplasty in fast-track departments in Denmark from 2005 
to 2011. Acta Orthopaedica 2014; 85:493-500.

http://dx.doi.org/10.3109/17453674.2014.942586

40. Kable A, Gibberd R, Spigelman A. Complications after discharge for surgical patients. ANZ Journal of Surgery 2004; 74:92-97.

http://dx.doi.org/10.1046/j.1445-2197.2003.02922.x

41. Janušonis V. Nepageidautinų įvykių pranešimų sistemos sveikatos priežiūros organizacijose. Sveikatos mokslai, 2005;15:7580.

42. Morris AM, Baldwin LM, Matthews B. et al. Reoperation as a quality indicator in colorectal surgery: a population-based analysis. Annals of Surgery 2007; 245:73-79.

http://dx.doi.org/10.1097/01.sla.0000231797.37743.9f

43. Merkow RP, Bilimoruia KY, Cohen ME. et al. Variability in reoperation rates at 182 hospitals: a potential target for quality improvement. American Journal of Colorectal Surgery 2009; 209:557-564.

http://dx.doi.org/10.1016/j.jamcollsurg.2009.07.003

44. Cathpole K. Errors in the operating theatre - how to spot and stop them. Journal of Health Services Research and Policy 2010;15 Suppl.:48-51.

http://dx.doi.org/10.1258/jhsrp.2009.09s 105

45. Janušonis V. Rizikos valdymas sveikatos priežiūros organizacijose. Klaipėda: S. Jokužio leidykla- spaustuvè, 2005.

46. Almoudaris AM, Burns EM, Mamidanna R. et al. Value of failure to rescue as a marker of the standard of care following reoperation for complications after colorectal resection. British Journal of Surgery 2011; 98:1775-1783. http://dx.doi.org/10.1002/bjs.7648

47. Stamos MJ. Reoperative surgery. Clinics in Colon and Rectal Surgery 2006; 19:179-180. http://dx.doi.org/10.1055/s-2006-956437

48. Kmietowicz Z. Hospital infection rates in England out of control. BMJ 2000; 320:534-534. http://dx.doi.org/10.1136/bmj.320.7234.534

49. Kirkland KB, Briggs JP, Trivette SL. et al. The impact of surgical - site infections in the 1990s: attributable mortality, excess length of hospitalization, and extra costs. Infection Control and Hospital Epidemiology. 1999; 20:725-730. http://dx.doi.org/10.1086/501572

50. Havard D, Skramm I, Lower HL. et al. Infection after primary hip arthroplasty. Acta Orthopedics 2011; 81:646-654.

51. Longo WE, Virgo KS, Johnson FS. et al. Risk factors for morbidity and mortality after colectomy for colon cancer. Disease Colon Rectal Journal 2000; 43:83-91. http://dx.doi.org/10.1007/BF02237249

52. Smith $M$. The paradox of the risk society state. British Journal of Politics and International Relations 2004; 6:312-332. http://dx.doi.org/10.1111/j.1467-856X.2004.00142.x

53. Flynn R. Clinical governance and governmentality. Health, Risk and Society 2002; 4:155-173. http://dx.doi.org/10.1080/13698570220137042

54. Thurston A. Sacred rituals in the operating theatre: Summarising the science. Current Orthopedics 2004; 18:135-146. http://dx.doi.org/10.1016/j.cuor.2004.02.006

55. Department of Health. An organization with a memory. The report of an expert group on learning from adverse events. London: Stationery Office; 2000.
56. McLeod RS, Bohnen JM. Canadian Association of General Surgeons Evidence Based Reviews in Surgery. 9 Risk factors for retained foreign bodies after surgery. Canadian Journal of Surgery 2004; 47:57-59.

\section{REPEAT SURGERY}

V. Janušonis

Key words: repeat surgery, health care quality, adverse events. Summary

The aim of the study was to evaluate the contingent of patients who underwent a reoperation, the surgery profile their caus al factors, risks, the avoidance possibilities, and to compare the repeat surgery assessments made by surgeons and experts.

Material and methods. From January 2000 to December 2014 a survey was carried out in Klaipeda University Hospital. The study included 757 inpatients, who underwent a reoperation. The data was collected via adverse event (reoperation) reporting forms. The findings of surgeons and experts estimations of reoperations according to surgery profile, patients' age and gender during the periods of 2000-2004, 2005-2009 and 2010-2014 were analized and compared.

Results. The research showed that reoperation was carried out on $0.31 \%$ of the surgery patients. More than one quarter $(27.7 \%)$ of all adverse events were repeat surgery (reoperations). The greatest number of reoperations was abdominal and endocrine profile surgery $(58.8 \%)$ of the average risk (51.7\%). Many patients $(39.8 \%)$ who underwent a reoperation had oncology diseases, part $(11.2 \%)$ of them had links with infection.

The main cause of repeat surgery was individual characteristics of patients $(85.3 \%$ by surgeons' and $89.6 \%$ by experts' assessments). Most of reoperations (60.2\% in surgeons' and $66.7 \%$ experts' opinion) were totally or partly avoidable.Conclusions. The main repeat surgery indicators - causes, degree of risk, the period of time between operation and reoperation - assessment of surgeons and experts were similar in the analysed periods.

The part of repeat surgery in a high operation activity Klaipeda University Hospital with a large multi-profile developed infrastructure, providing the around the clock emergency medical care, was small and relatively stable.

The main reason of reoperations was patients' individual characteristics. The part (two- fifth) of the patients had oncology diseases, one of six reoperations had links with infection.

The increase of the operational activity, the number of operations, and the operations complexity results in the increase of the repeat surgery and risk degree. The majority (two- thirds) of the reoperations could have been avoided with the application of multivalent prevention measures.

Correspondence to: janusonis@kul.lt

Gauta 2015-09-07 